\title{
Faktor yang Mempengaruhi Minat Beli, Kepuasan Konsumen dan Peluang Pasar Smartphone di Indonesia
}

\author{
${ }^{1}$ Ruth Mariana Bunga Wadu*, ${ }^{2}$ Rio Wirawan \\ Program Studi Sistem Informasi, Fakultas Ilmu Komputer, UPN Veteran Jakarta \\ *ruthbungawadu@upnvj.ac.id
}

\begin{abstract}
Abstrak. Perkembangan teknologi, meningkatnya kebutuhan dan daya beli masyarakat menjadi faktor meningkatnya pengguna smartphone. Penelitian ini mencoba meneliti faktor yang mempengaruhi minat beli konsumen terhadap perangkat smartphone android, blackberry, apple dan nokia, dan kepuasan konsumen terhadap system operasi yang digunakan yaitu android, blackberry OS, iOS (Apple), Symbian (Nokia). Serta mengetahui peluang pasar smartphone-smartphone tersebut di Indonesia. Variabel terikat yang digunakan adalah kepuasan konsumen dan variabel bebas adalah fitur, stabilitas \& kehandalan, keakuratan, fleksibilitas, kemudahan, ketepatan waktu, keamanan, Produktivitas dan dokumentasi.Ketersediaan fitur adalah faktor utama yang mempengaruhi minat beli konsumen. Stabilitas \& kehandalan, keakuratan, fleksibilitas, dan ketepatan waktu adalah variabel-variabel yang mempengaruhi kepuasan konsumen. Pada smartphone blackberry layanan web dan internet adalah faktor utama yang mempengaruhi minat beli konsumen dan fitur adalah variabel yang mempengaruhi kepuasan konsumen. Smartphone iOS (Apple) diperoleh faktor yang mempengaruhi minat beli konsumen adalah desain, layanan web dan internet. Kemudahan penggunaan serta dokumentasi adalah variabel yang mempengaruhi kepuasan konsumen. Smartphone symbian (Nokia) diperoleh harga merupakan faktor yang mempengaruhi minat beli konsumen dan varabel fitur, ketepatan waktu, dan dokumentasi adalah variabel yang mempengaruhi kepuasan konsumen. Hasil analisis SWOT diperoleh smartphone android, blackberry, iOS (Apple) dan Symbian (Nokia) terletak pada kuadran I yaitu perusahaan memiliki peluang dan kekuatan yang dapat dimanfaatkan untuk berkembang dan menguasai pangsa smartphone di Indonesia. iOS (Apple) terletak pada kuadran II yaitu menunjukan bahwa perusahaan memiliki kekuatan yang lebih besar daripada kelemahan dan peluang lebih kecil daripada ancaman. Untuk memperkecil ancaman perusahaan perlu melakukan Diversifikasi Strategi dengan menggunakan kekuatan untuk memanfaatkan peluang jangka panjang.
\end{abstract}

Kata kunci: Smartphone, Kepuasan Pelanggan, Analisis SWOT

\section{PENDAHULUAN}

Kemajuan teknologi membawa dampak pada perkembangan handphone (telepon genggam), jika pada sebelumnya handphone hanya digunakan untuk melakukan layanan pesan singkat / sms (sort message service) dan layanan komunikasi suara, maka sekarang ini handphone telah mengalami pergeseran fungsi dan manfaat seiring dengan meningkatnya kebutuhan, mobilitas serta daya beli masyarakat, yang menuntut kecepatan dalam proses mengakses informasi. Handphone sekarang dituntut untuk dapat melakukan berbagai macam tugas seperti PC (Personal Computer) yaitu handphone harus memiki fitur hiburan ( music, gambar, video, game), komunikasi ( sms, telepon, email, mms ), Pengolahan data ( Office ), Alat Kerja ( Scanner, Pengontrol presentasi), Media Sosial (Facebook, Twitter,dll). Untuk memenuhi kebutuhan masyarakat, produsen telepon seluler saling bersaing mengeluarkan produk baik preangkat keras dan perangkat lunak, dan salah satu inovasi dalam bidang teknologi dan komunikasi adalah smartphone (telepon pintar).

Indonesia sebagai negara berkembang memiliki karakteristik pengguna smartphone yang mencari lebih dari telepon sederhana dan smartphone bisnis. Oleh sebab itu sangat dibutuhkan ketersediaan sisem operasi 
yang canggih dan update seperti kemudahan pengoperasian, kecepatan akses, keamanan data dan berbagai macam aplikasi yang mendukung user dalam melakukan kegiatan mobile. Smartphone yang telah menjadi populer di dunia kian mendominasi pasar siap untuk menggeser keberadaan ponsel fitur, hal ini dibuktikan dengan lebih dari setengah pengguna yang berusia antara 18-44 tahun memiliki smartphone.

Menurut hasil survei Nilesen terbaru (Januari 2012) yaitu 45\% orang yang menggunakan ponsel memiliki smartphone, sementara dalam tiga bulan terkahir $60 \%$ orang yang membeli perangkat telah menggunakan smartphone dan bukan ponsel fitur. Menyadari keberadaan smartphone yang begitu populer dibandingkan ponsel fitur perusahaan-perusahaan industri dan teknologi di dunia seperti Apple (IOS), Android, Blackberry (RIM), dan Symbian (Nokia) berusaha membuat dan mengembangkan sistem operasi untuk memenuhi kebutuhan konsumen dan memenangkan pangsa pasar industri teknologi di dunia.

Tabel 1. Pangsa Pasar dan Total Penjualan Smartphone tahun 2011 di Dunia

\begin{tabular}{|l|c|c|}
\hline \multicolumn{1}{|c|}{ Sistem Operasi } & Total Penjualan Per Unit & Pangsa Pasar (\%) \\
\hline Android & $46,775.9$ & 43.4 \\
\hline Symbian (Nokia) & $23,853.2$ & 22.1 \\
\hline iOS & $19,628.8$ & 18.2 \\
\hline Research In Motion (Blackberry) & $\mathbf{1 2 , 6 5 2 . 3}$ & $\mathbf{1 1 . 7}$ \\
\hline
\end{tabular}

Banyaknya bermunculan perangkat smartphone menawarkan produk sejenis dengan fitur yang menarik, harga yang kompetitif, service lebih, dan kinerja produk yang baik. Pengukuran kinerja dan kepuasan pelanggan merupakan salah satu faktor yang penting dalam perusahaan. Dengan adanya pengukuran tingkat kepuasan pelanggan terhadap sistem operasi android, apple, blackberry dan nokia maka, manajemen android, apple, blackberry dan nokia dapat memperoleh dasar yang obyektif untuk memperoleh gambaran tingkat kualitas produk sistem operasi, serta faktor-faktor yang mempengaruhi kepuasan pelanggan.

Menurut Fandy Tjipoto, Greghorius Chandra, Dadi Adriana (Pemasaran Strategik, 2007) kepuasan pelanggan merupakan konsep sentral dalam wacana bisnis dan manajemen. Konsekuensi kepuasan pelanggan /ketidakpuasan pelanggan sangat kruasial bagi kalangan bisnis, pemerintah, dan konsumen. Bagi bisnis kepuasan pelanggan dipandang sebagai salah satu dimensi kinerja pasar. Peningkatan kepuasan pelanggan berpotensi mengarah pada pertumbuhan penjualan jangka panjang dan pendek, serta pangsa pasar sebagai hasil pembelian ulang. Ketidakpuasan pelanggan memunculkan sejumlah resiko, seperti boikot atau protes dari lembaga konsumen, intervensi dan pemerintahan, rekasi pesaing, dan masuknya produk subtitusi baru ke pasar. Ketidakpuasan pelanggan sesungguhnya dapat membantu perusahaan mengidentifikasi aspek-aspek yang menjadi kelemahan produk atau jasanya yang tidak mampu memenuhi standar konsumen dan pemerintah, serta dapat membantu perusahaan dalam memperkokoh posisi bersaing produk melalui segmentasi.

\section{METODE PENELITIAN}

Penelitian analisis sistem operasi smartphone android, blackberry, iOS (Apple), dan Symbian (Nokia), terdiri dari dimensi-dimensi yaitu faktor yang mempengaruhi minat beli konsumen, kepuasan konsumen dan peluang pasar dari smartphone android, blackberry, iOS (Apple), dan Symbian (Nokia).

Proses pengumpulan data menggunakan kuesioner online dari google doc https://docs.google.com/spreadsheet/viewform? formkey=dG1PeDh5UEk5VF96bFRwZS1UMGZHbWc6 MQ dan kuesioner manual. Masa waktu pengisian kuesioner adalah satu (1) bulan yaitu dimulai pada bulan Juni 2012 sampai Juli 2012. Kuesioner ini disebarkan secara acak kepada daftar sampel responden yang ditentukan sebelumnya dari sejumlah populasi pengguna perangkat smartphone berbasis sistem opeasi android, blackberry, iOS (Apple) dan Symbian (Nokia) yang tersebar di beberapa propinsi. 
Faktor yang mempengaruhi minat beli konsumen diukur menggunakan indikator harga, desain, fitur, kualitas koneksi, audio music, kualitas layer, aplikasi, web dan internet, daya tahan baterai, garansi dan service pasca beli, ketersediaan perlengkapan di pasaran, merk, dukungan lokasi dan tampilan antar muka. Kepuasan pelanggan diukur menggunakan indikator pengukuran yang merupakan variabel bebas yaitu kinerja, fitur, keakuratan, fleksibiltas, kemudahan penggunaan, ketepatan waktu, keamanan, produktivitas, dan dokumentasi. Peluang pasar diukur menggunakan analisis SWOT dengan menganalsis kekuatan, kelemahan, peluang dan ancaman.

\section{HASIL DAN ANALISIS AND ANALISIS}

Berdasarkan hasil pengumpulan data diperoleh 112 responden yang tersebar di beberapa propinsi di Indonesia.

3.1 Faktor yang mempengaruhi minat beli konsumen Android, Blackberry, IOS (Apple ) dan Symbian (Nokia )

Berdasarkan tabel 2 dapat di identifikasi bahwa sebesar 15 responden dari total 20 responden, memilih fitur sebagai pertimbangan utama dalam membeli perangkat smartphone android. Pada perangkat blackberry diketahui yaitu, sebanyak 36 responden dari total 52 responden memilih web dan internet sebagai pertimbangan utama dalam membeli smartphone blackberry. Pada perangkat iOS (Apple) faktor utama yang menjadi pertimbangan konsumen dalam membeli adalah desain yang menarik dan penggunaan web dan internet, dengan jumlah responden sebanyak 5 orang, dari total keseluruhan jumlah responden sebanyak 5 orang. dan Pada perangkat Symbian (Nokia) diketahui bahwa faktor utama yang menjadi pertimbangan konsumen dalam memilih smartphone symbian (nokia) adalah harga dengan jumlah responden 22 orang dari total responden 25 responden.

Tabel 2. Faktor yang mempengaruhi minat beli konsumen Android, Blackberry, IOS (Apple) dan Symbian (Nokia)

\begin{tabular}{|l|c|c|c|c|}
\hline \multirow{2}{*}{ Faktor } & \multicolumn{3}{c|}{ Platform } \\
\cline { 2 - 5 } & Android & Blackberry OS & iOS & $\begin{array}{c}\text { Nokia } \\
\text { (Symbian) }\end{array}$ \\
\hline Harga & 13 & 34 & 10 & 22 \\
\hline Desain & 7 & 25 & 15 & 13 \\
\hline Fitur & 15 & 28 & 11 & 16 \\
\hline Kualitas Koneksi & 7 & 20 & 10 & 7 \\
\hline Audio Musik & 8 & 8 & 9 & 10 \\
\hline Kualitas Layar & 7 & 8 & 14 & 6 \\
\hline Aplikasi & 13 & 30 & 14 & 10 \\
\hline Web dan Internet & 13 & 36 & 15 & 6 \\
\hline Daya Tahan Baterai & 7 & 6 & 7 & 11 \\
\hline Garansi dan Service pasca beli & 5 & 9 & 6 & 6 \\
\hline $\begin{array}{l}\text { Ketersediaan perlengkapan di } \\
\text { pasaran }\end{array}$ & 3 & 10 & 2 & 2 \\
\hline Merek & 4 & 16 & 14 & 11 \\
\hline Dukungan Lokasi & 1 & 7 & 6 & 1 \\
\hline Tampilan Antara Muka & 3 & 6 & 6 & 1 \\
\hline Other & 0 & 0 & 0 & 0 \\
\hline
\end{tabular}




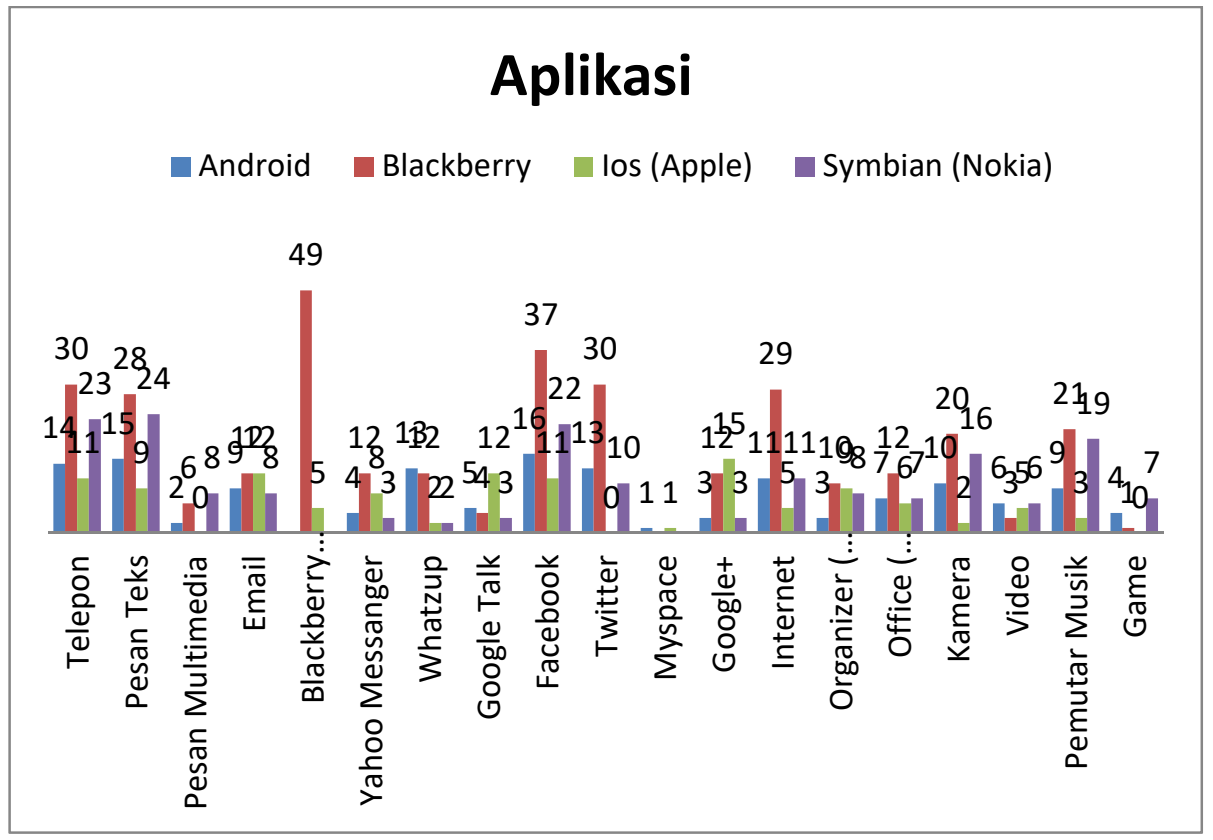

Gambar 1. Aplikasi yang paling sering digunakan

Berdasarkan gambar 1 diatas dapat diidentifikasi bahwa, pada perangkat android, Aplikasi yang paling sering digunakan oleh respnoden pada perangkat android adalah sosial media facebook, dengan jumlah responden 16 orang dari total responden 20 orang. Aplikasi yang paling sering digunakan oleh respoden pada perangkat Blackberry adalah Blackberry Messager, dengan jumlah responden 49 orang dari toal responden 52 orang. Aplikasi yang paling sering digunakan oleh mayoritas responden pada perangkat Ios(Apple) adalah Telepon, Email, dan Facebook dengan jumlah responden 4 orang dari total responden 5 orang dan Aplikasi yang paling sering digunakan oleh mayoritas responden pada perangkat Symbian (Nokia) adalah Pesan teks dengan jumlah responden 24 orang dari total responden 25 orang.

Facebook merupakan aplikasi yang paling sering digunakan oleh pengguna android ketimbang aplikasi lainnya. Hal ini dikarenakan facebook merupakan salah satu aplikasi media sosial yang sangat popular saat ini, penggunanya pun dari berbagai kalangan usia, tingkat sosial, pekerjaan dan pendidikan. Selain itu, Facebook merupakan sebuah sarana sosial yang membantu masyarakat untuk berkomunikasi secara lebih effisien dengan teman-teman, keluarga dan teman sekerja. melalui facebook dapat memudahkan pengguna dalam berbagi informasi melewati social graph, digital mapping kehidupan real hubungan sosial manusia. Siapun boleh mendaftar di Facebook dan erinteraksi dengan orang-orang yang mereka kenal dalam lingkungan saling percaya.

Backberry Messager (BBM) adalah aplikasi yang paling sering digunakan oleh pengguna blackberry dibandingkan aplikasi lainnya. Hal ini dikarenakan Blackberry Messager merupakan media komunikasi real time yang dapat mengirimkan dan menerima pesan dalam hitungan detik dan dapat ketahui bila kontak mengetik balasan, serta pengguna dapat mengirimkan ile atau chatting (obrolan) dengan teman yang terdaftar pada kontak Blackberry Messager sewaktu membuka aplikasi yang tersambung ke Blackberry Messager.

Internet, Email dan Facebook merupakan aplikasi yang paling sering digunakan oleh pengguna Ios (Apple). Koneksi internet pada iPhone terdapat dua pilihan yaitu 3G dan HSDPA di jalur selular dan wifi. selain itu, iPhone dapat difungsikan sebagai modem baik lewat bluetooth, kabel data, dan wifi. Browser pada iPhone menggunakan safari yang memberikan kemampuan untuk membuka beberapa jendela halaman browser baru dengan maximal 8 halaman baru. iPhone memiliki beberapa server email ternama seperti Yahoo, Gmail, MobileMe, dan Microsoft Exchange. Serta kemampuan membaca beberapa format file pada email seperti doc, docx, htm, key, numbers, pages, pdf, ppt, pptx, rtf, txt, vcf, xls, dan xlsx. dan Facebook 
merupakan aplikasi yang harus di download (unduh) pada App Store. Kelebihan yang dimiliki aplikasi facebook pada iPhone yaitu pengguna dapat melakukan chatting langsung di iPhone.

Pesan Teks adalah aplikasi yang paling sering digunakan oleh pengguna Symbian (Nokia) dibandingkan aplikasi lainnya. Hal ini menunjukan bahwa kegiatan mengirim pesan singkat yang merupakan salah satu fungsi dasar dari sebuah handphone, masih sangat populer dikalangan pengguna syambian (Nokia). Pada symbian OS terdapat Messaging framework yang mendukung pengiriman dan penerimaan pesan SMS, email dan fax. Framework memanfaatkan polymorphic MTMs (message type modules) untuk menangani tipe pesan yang spesifik. Perubahan besar pada symbian 6.0 adalah penambahan watchers yang menangani pesan masuk dan BIO messaging yang mendukung pengiriman pesan ke system daripada ke pengguna. Symbian versi 6.1 menambahkan dukungan GPRS dan 2D kompresi fax.

\subsection{Kepuasan konsumen sistem operasi Android, Blackberry, IOS (Apple ) dan Symbian (Nokia )}

Tabel 3. Hasil Uji Regresi Liner Berganda

\begin{tabular}{|l|r|r|r|r|}
\hline \multirow{2}{*}{} & \multicolumn{4}{|c|}{ Coefficients $^{\mathbf{a}}$} \\
\cline { 2 - 5 } & Android & Blackberry OS & Ios (Apple) & $\begin{array}{c}\text { Symbian } \\
\text { (Nokia) }\end{array}$ \\
\hline Model & Sig. & Sig. & Sig. & \multicolumn{1}{|c|}{ Sig. } \\
\cline { 2 - 5 } (Constant) & 0,121 & 0,84 & 0,655 & 0,788 \\
Fitur & 0,081 & $\mathbf{0 , 0 0 1}$ & 0,381 & $\mathbf{0 , 0 0 4}$ \\
Stabilitas_Kehandalan & $\mathbf{0 , 0 2 8}$ & 0,227 & 0,415 & 0,612 \\
Keakuratan & $\mathbf{0 , 0 3}$ & 0,226 & 0,131 & 0,054 \\
Fleksibilitas & $\mathbf{0 , 0 0 6}$ & 0,185 & 0,635 & 0,995 \\
Kemudahan & 0,318 & 0,464 & $\mathbf{0 , 0 1 6}$ & 0,338 \\
Ketepatan_Waktu & $\mathbf{0 , 0 6 4}$ & 0,214 & 0,488 & $\mathbf{0 , 0 1 5}$ \\
Keamanan & 0,189 & 0,121 & 0,828 & 0,659 \\
Produktifitas & 0,406 & 0,656 & 0,663 & 0,6 \\
Dokumentasi & 0,102 & 0,207 & $\mathbf{0 , 0 2 0}$ & $\mathbf{0 , 0 0 1}$ \\
\hline a. Dependent Variable: & \multicolumn{5}{c}{} \\
\multicolumn{2}{|c|}{ Kepuasan_Konsumen } & & &
\end{tabular}

Berdasarkan hasil uji regresi linear berganda pada tabel 3 di atas dapat disimpulkan bahwa kepuasan konsumen pengguna sistem operasi android terutama variabel independen, memiliki nilai signifikan lebih kecil dari derajat signifikan $\alpha$ (p-value $<0.05)$. Variabel Stabilitas dan Kehandalan $(0.028)$, Keakuratan (0.030), Fleksibilitas (0.006) dan Ketepatan Waktu $(0,015)$ Hal menunjukan secara variabel-variabel tersebut signifikan mempengaruhi kepuasan konsumen terhadap sistem operasi android. Variabel Kemudahan, Keamanan, Produktivitas dan dokumentasi memiliki nilai p-value lebih besar dari derajat signifikan $\alpha$ (p-value $>0.10)$. Hal ini menunjukan bahwa variabel-variabel tersebut tidak memiliki pengaruh yang signifikan mempengaruhi kepuasan konsumen sistem operasi android.

Pada pengujian sistem operasi blackberry diketahui bahwa kepuasan konsumen pengguna sistem operasi blackberry terutama variabel independen Fitur (0.001) memiliki nilai signifikan lebih kecil dari derajat signifikan $\alpha(\mathrm{p}$-value $<0.10)$. Hal menunjukan secara variabel Fitur signifikan mempengaruhi kepuasan konsumen terhadap sistem operasi blackberry. Variabel Stabilitas dan Kehandalan (0.227), Keakuratan (0.226), Fleksibilitas (0.185), Kemudahan (0.464), Ketepatan Waktu (0.214), Keamanan (0.121), Produktivitas (0.656) dan dokumentasi (0.207) memiliki nilai p-value lebih besar dari derajat signifikan $\alpha$ (p-value $>0.10)$. Hal ini menunjukan bahwa variabel-variabel tersebut tidak memiliki pengaruh yang signifikan terhadap kepuasan konsumen pengguna sistem operasi blackberry

Pada pengujian sistem operasi iOS(Apple) diketahui bahwa, kepuasan konsumen pengguna sistem operasi iOS(Apple) terutama variabel independen Kemudahan (0.016) dan Dokumentasi $(0,020)$ memiliki nilai 
signifikan lebih kecil dari derajat signifikan $\alpha$ (p-value $<0.10)$. Hal ini menunjukan secara variabel Fitur signifikan mempengaruhi kepuasan konsumen terhadap sistem operasi iOS(Apple), Variabel Fitur $(0,381)$, Stabilitas dan Kehandalan $(0,415)$, Keakuratan $(0,131)$, Fleksibilitas $(0,635)$, Ketepatan Waktu $(0,488)$, Keamanan $(0,828)$ dan Produktivitas $(0,663)$ memiliki nilai p-value lebih besar dari derajat signifikan $\alpha$ ( $p$-value $>0.10)$. Hal ini menunjukan bahwa variabel-variabel tersebut tidak memiliki pengaruh yang signifikan terhadap kepuasan konsumen pengguna sistem operasi iOS.

Pada pengujian sistem operasi Symbian (Nokia) diketahui bahwa, kepuasan konsumen pengguna sistem operasi Symbian (Nokia) terutama variabel independen Fitur $(0,004)$, Ketepatan Waktu $(0,015)$ dan Dokumentasi $(0,001)$ memiliki nilai signifikan lebih kecil dari derajat signifikan $\alpha$ (p-value $<0.10)$. Hal menunjukan secara variabel fitur signifikan mempengaruhi kepuasan konsumen terhadap sistem operasi Symbian (Nokia). Variabel Stabilitas dan Kehandalan (0,612), Fleksibilitas (0,995), Kemudahan (0338), Keamanan $(0,659)$ dan Produktivitas $(0,600)$ memiliki nilai p-value lebih besar dari derajat signifikan $\alpha(p-$ value $>0.10$ ). Hal ini menunjukan bahwa variabel-variabel tersebut tidak memiliki pengaruh yang signifikan terhadap kepuasan konsumen pengguna sistem operasi symbian (Nokia).

Tabel 4. Koefisien Korelasi Berganda dan Koefisien Determinasi.

Model Summary

\begin{tabular}{|l|r|r|r|r|r|}
\hline \multicolumn{1}{|c|}{ Sistem Operasi } & Model & R & R Square & Adjusted R Square & $\begin{array}{c}\text { Std. Error } \\
\text { of the } \\
\text { Estimate }\end{array}$ \\
\hline Android & 1 &, $974^{\mathrm{a}}$ & 0,948 & 0,901 & 1,081 \\
\hline Blackberry OS & 1 &, $873^{\mathrm{a}}$ & 0,762 & 0,711 & 2,051 \\
\hline Ios (Apple) & 1 &, $981^{\mathrm{a}}$ & 0,962 & 0,895 & 0,984 \\
\hline Symbian (Nokia) & 1 &, $930^{\mathrm{a}}$ & 0,865 & 0,784 & 1,897 \\
\hline
\end{tabular}

a. Predictors: (Constant), Dokumentasi, Kemudahan, Keakuratan,

Stabilitas_Kehandalan, Keamanan, Produktifitas, Fitur, Fleksibilitas,

Ketepatan_Waktu

Nilai korelasi berganda $(R)$ pada yang merupakan nilai korelasi antara variabel independen terhadap, variabel dependen yaitu kepuasan konsumen pengguna sistem operasi android. Nilai R berkisar antara 1 sampai 0 , jika mendekati 1 maka hubungan semakin kuat. Sebaliknya jika mendekati 0 maka hubungan semakin lemah. Nilai R Square $\left(\mathrm{R}^{2}\right)$ yaitu menunjukan koefisien determinasi yang digunakan untuk mengetahui seberapa besar presentase sumbangan variebl independen secara bersama-sama terhadap variabel dependen.

Pada perhitungan pertama yaitu android memiliki nilai $\mathrm{R}=0.901$ yang mendekati angka 1 . Hal ini menjelaskan bahwa korelasi antara variabel independen yaitu Kinerja dan fitur, stabilitas dan kehandalan, Fleksibiltas, Kemudahan penggunaan, Ketepatan waktu, Keamanan, Produktifitas dan Dokumentasi terhadap tingkat kepuasan konsumen pengguna sistem operasi android memiliki hubungan yang kuat.

Dari hasil penelitian, diketahui nilai $\mathrm{R}^{2}$ sebesar 0.948 . Hal ini menjelaskan bahwa presentase sumbangan pengaruh variabel independen yaitu Kinerja dan fitur, stabilitas dan kehandalan, Fleksibiltas, Kemudahan penggunaan, Ketepatan waktu, Keamanan, Produktifitas dan Dokumentasi terhadap tingkat kepuasan konsumen adalah sebesar 94.8\% sedangkan sisanya $(100 \%-94.8 \%=5.2 \%)$ dipengaruhi oleh faktor lain yang tidak diteliti.

Pada perhitungan kedua yaitu blackberry OS memiliki nilai $\mathrm{R}=0,762$ yang mendekati angka 1 . Hal ini menjelaskan bahwa korelasi antara variabel independen yaitu Kinerja dan fitur, stabilitas dan kehandalan, Fleksibiltas, Kemudahan penggunaan, Ketepatan waktu, Keamanan, Produktifitas dan Dokumentasi terhadap tingkat kepuasan konsumen pengguna sistem operasi blackberry memiliki hubungan yang kuat. dan nilai $\mathrm{R}^{2}$ sebesar 0,711 menjelaskan bahwa presentase sumbangan pengaruh variabel independen yaitu 
Kinerja dan fitur, stabilitas dan kehandalan, Fleksibiltas, Kemudahan penggunaan, Ketepatan waktu, Keamanan, Produktifitas dan Dokumentasi terhadap tingkat kepuasan konsumen adalah sebesar $71,1 \%$ sedangkan sisanya $(100 \%-71,1 \%=28,9 \%)$ dipengaruhi oleh faktor lain yang tidak diteliti.

Pada perhitungan ketiga yaitu iOS (Apple) ini memiliki nilai $\mathrm{R}=0,962$ yang mendekati angka 1 . Hal ini menjelaskan bahwa korelasi antara variabel independen yaitu Kinerja dan fitur, stabilitas dan kehandalan, Fleksibiltas, Kemudahan penggunaan, Ketepatan waktu, Keamanan, Produktifitas dan Dokumentasi terhadap tingkat kepuasan konsumen pengguna sistem operasi blackberry memiliki hubungan yang kuat .

Nilai $\mathrm{R}^{2}$ sebesar 0,962 . Hal ini menjelaskan bahwa presentase sumbangan pengaruh variabel independen yaitu Kinerja dan fitur, stabilitas dan kehandalan, Fleksibiltas, Kemudahan penggunaan, Ketepatan waktu, Keamanan, Produktifitas dan Dokumentasi terhadap tingkat kepuasan konsumen adalah sebesar 96,2\% sedangkan sisanya $(100 \%-96,2 \%=3,8 \%)$ dipengaruhi oleh faktor lain yang tidak diteliti.

Pada perhitungan keempat yaitu Symbian (Nokia) memiliki nilai $\mathrm{R}=0,930$ yang mendekati angka 1 . Hal ini menjelaskan bahwa korelasi antara variabel independen yaitu Kinerja dan fitur, stabilitas dan kehandalan, Fleksibiltas, Kemudahan penggunaan, Ketepatan waktu, Keamanan, Produktifitas dan Dokumentasi terhadap tingkat kepuasan konsumen pengguna sistem operasi symbian memiliki hubungan yang kuat . dan nilai $\mathrm{R}^{2}$ sebesar 0,930 . Hal ini menjelaskan bahwa presentase sumbangan pengaruh variabel independen yaitu Kinerja dan fitur, stabilitas dan kehandalan, Fleksibiltas, Kemudahan penggunaan, Ketepatan waktu, Keamanan, Produktifitas dan Dokumentasi terhadap tingkat kepuasan konsumen adalah sebesar $93 \%$ sedangkan sisanya $(100 \%-93 \%=7 \%)$ dipengaruhi oleh faktor lain yang tidak diteliti.

\subsection{Peluang pasar Android, Blackberry, IOS (Apple) dan Symbian (Nokia) di Indonesia}

Tabel 5. Hasil SWOT Android, Blackberry, iOS dan Symbian

\begin{tabular}{|c|c|c|c|c|c|c|c|c|}
\hline NO & SISTEM OPERASI & PELUANG & ANCAMAN & SKOR & KEKUATAN & KELEMAHAN & SKOR & KUADRAN \\
\hline 1 & Android & 1.45 & 1.35 & $\mathbf{2 . 8}$ & 2.25 & 0.40 & $\mathbf{2 . 6 5}$ & I \\
\hline 2 & Blackberry OS & 1.45 & 0.90 & $\mathbf{2 . 3 5}$ & 2.0 & 0.80 & $\mathbf{2 . 8 0}$ & I \\
\hline 3 & iOS (Apple) & 1.15 & 1.30 & $\mathbf{2 . 4 5}$ & 1.33 & 1.07 & $\mathbf{2 . 4 0}$ & II \\
\hline 4 & Symbian & 1.50 & 0.55 & $\mathbf{2 . 1 5}$ & 1.60 & 0.55 & $\mathbf{2 . 1 5}$ & I \\
\hline
\end{tabular}

Android memiliki nilai pangsa pasar pada kuartal II 2012 pangsa pasar android di indonesia mencapai 11.75 $\%$. Hasil yang cukup memuaskan ditengah persaingan ketat smartphone. Dengan sistem operasi terbuka milik google serta digunakan oleh berbagai vendor lokal maupun global andorid mampu memasuki pangsa pasar indonesia yang beberapa tahun belakangan ini didominasi oleh smatphone blackberry dan symbian. kondisi ini sesuai dengna hasil analisis SWOT pada gambar 4.1 posisi android berada pada kuadran I. sumbu X bernilai positif berati memiliki kekuatan (S) yang lebih besar daripada kelemahan (W). Sedangkan untuk sumbu $Y$ bernilai positif dimana peluang $(\mathrm{O})$ lebih kecil dibandingkan ancaman $(\mathrm{T})$. Hal ini merupakan situasi yang sangat menguntungkan. android memiliki peluang dan kekuatan untuk berkembang dan mengusai pangsa pasar smartphone di Indonesia. Dengan kekuatan dan peluang yang kuat, maka strategi yang harus diterapakan dalam kondisi ini adalah mendukung kebijakan pertumbuhan yang agresif. Sebagai sistem operasi yang digunakan oleh berbagai vendor, andorid tentunya tidak terikat pada salah satu merek smartphone, oleh karena itu perangkat berbasis sistem operasi android dapat dimiliki dengan range harga termurah sampai termahal, dan dengan dukungan vendor-vendor berkelas. Hal ini mengakibatkan android dapat menyentuh semua segmen masyarakat. Perluasan jaringan distribusi merupakan strategi yang perlu diterapkan oleh android. dimana dengan perlusan jaringan distribusi android, 
diharapkan masyarakat dengan lebih mudah memiliki smartphone android dengan kondisi demografi indonesia yang sangat luas. Peningkatan kerja sama dengan vendor-vendor global maupun lokal sangat menguntungkan android karena memperluas produk smarphone berbasis android dan menyebabkan semakin banyak pilihan merek terhadap smartphone berbasis android di masyarakat. Peningkatan kerja sama dengan pihak pengembang. Sebagai sistem operasi terbuka, android memiliki sistem operasi yang dapat dikembangkan oleh pihak ke-tiga, dengan adanya kerja sama yang baik antara andorid dan pihak pengembang sistem opersi dapat di modifkasi dan dibuat aplikasi sesuai dengan kebutuhan konsumen dan perkembangan teknologi.

Blackberry merupakan sistem operasi smartphone yang beberapa tahun belakangan sangat mendominasi pangsar pasar smartphone. pada kuartal II 2012 pangsa pasar blackberry mengalami penurunan sebesar $15.47 \%$ dan tertinggal jauh dibawah kompetitor-kompetitor smartphone lainnya seperti Android dan Symbian. Kondisi ini cukup sinkron dengan hasil analisi SWOT, dimana posisi blackberry berada pada kuadran I. sumbu X bernilai positif, artinya memiliki kekuatan (S) yang lebih besar daripada kelemahan (W). sedangkan untuk sumbu Y juga memiliki nilai positif yang artinya peluang $(\mathrm{O})$ lebih besar daripada ancaman (W). Sehingga perlu dilakukan Growth oriented strategy yaitu strategi yang mendukung kebijakan pertumbuhan yang agresif. Hal ini sangat menguntungkan karena blackberry memiliki peluang dan kekuatan yang bisa dimanfaatkan. dikarenakan ancaman dan kelemahan. Pilihan strateginya adalah: Peningkatan kerja sama dengan operator lokal penyedia layanan telekomunikasi di Indonesia, guna mendukung layanan BIS (Blackberry internet service), yang diharapkan dengan meningkatnya layanan operator service terhadap konsumen blackberry melalui paket-paket layanan blackberry internet service yang memuaskan konsumen. Produsen blackberry perlu membuat inovasi-inovasi dibidang teknologi dan desaign untuk menghadapi persaingan teknologi smatphone, serta mengeluarkan produk dengan harga yang dapat menjangkau semua segmen masyarakat.

iOS (Apple) merupakan smarphone dengan pangsa pasar yang tergolong kecil di Indonesia dengan rata-rata pertumbuhan pertahunnya sebesar $0.28 \%$. Dalam tabel 5 posisi IOS berada pada kuadran II. sumbu X bernilai positif yaitu memiliki kekuatan (S) yang lebih besar daripada kelemahan (W). Pengalaman sebagai produsen perangkat keras dan perangkat lunak selama puluhan tahun serta dukungna developer yang handal menjadikan apple tetap mampu bersaing di pasar smartphone indonesia. Sedangkan untuk sumbu Y bernilai negatif yaitu memiliki peluang (O) lebih kecil daripada ancaman (W). Sehingga perlu dilakukan beberapa Diversifikasi Strategi untuk memperkecil faktor ancaman dan selalu menjaga Peluang bisnis. dengan melihat kondisi saat ini dan prediksi mendatang, masih cukup menguntungkan bagi apple untuk melebarkan usahanya. Diversifikasi Strategi merupakan kondisi dimana perusahaan mengalami ancaman namun masih memiliki kekuatan dari segi internal. strategis yang harus diterapkan adalah menggunakan kekuatan untuk memanfaatkan peluang jangka panjang. untuk mengantisipasi faktor ancaman yang bisa semakin meningkat, apple perlu melakukan langkah-langkah agar dapat menopang tantangan dan menjaga peluang. Strategi yang harus diterapkan adalah menyelesaikan masalah hukum untuk menghilangkan kasus pembajakan hak paten yang dilakukan oleh pihak kompetitor lainnya. Pihak apple diharapkan terus melalukan pengembangan inovasi teknologi dan aplikasi-aplikasi terbaru sesuai kebutuhan konsumen. Menetapkan strategis bisnis dengan menjalin kerja sama dengan distributor iphone di indonesia, seperti telkomsel dan XL untuk medapatkan promo-promo harga lebih murah dan cicilan harga, mengingat harga iphone masih sangat mahal dan hanya bisa menyentuh kalangan mengenah ke atas.

Symbian merupakan sistem operasi dengan pangsa pasar tertinggi selama 5 tahun belakangan dan terakhir pada kuartal II tahun 2012 symbian memiliki pangsa pasar sebesar 49.73\% di Indonesia. Pada tabel 5 posisi symnbian berada pada kuadran I. sumbu X bernilai positif yaitu memiliki kekuatan (S) yang lebih besar daripada kelemahan $(\mathrm{W})$. Sedangkan untuk sumbu Y bernilai positif yaitu memiliki peluang $(\mathrm{O})$ lebih besar daripada ancaman (W). Dimana perusahaan memiliki peluang dan kekuatan, sehingga perlu diterapkan Growth oriented strategy untuk mendukung kebijakan petumbuhan yang agreasif. Strategi yang perlu dilakuakan symbian adalah perlu melakukan peningkatan kerja sama dengan vendor-vendor pengguna sistem operasi syambian, untuk menghasilkan produk smartphone yang dapat menjangkau semua lapisan masyarakat. dengan tetap memperhatikan ketersediaan fitur, keakuratan pengolahan sistem operasi dan kehandalan dalam menajalankan aplikasi. 


\section{KESIMPULAN}

Faktor yang mempengaruhi minat beli konsumen terhadap smartphone android adalah ketersediaan fitur, dengan total responden sebanyak 15 responden. Pada smartphone Blackberry OS diperoleh layanan web dan internet merupakan faktor utama konsumen memilih blackberry OS dengan total respnden sebesar 36 responden. Untuk smartphone iOS(Apple) diperoleh faktor yang mempengaruhi minat konsumen adalah desain serta layanan web dan internet, dengan total masing-masing responden sebesar 15 responden. dan untuk smartphone symbian (Nokia) diperoleh harga merupakan faktor yang mempengaruhi minat konsumen dengan total responden sebesar 22 respoden.

Variabel yang mempengaruhi kepuasan konsumen menggunakan sistem operasi Android, Balckberry, IOS(Appel) dan Symbian (Nokia) yaitu:

1. Berdasarkan hasil penelitian dengan mengguanakan regresi linear berganda menunjukan bahwa Variabel Stabilitas dan Kehandalan (0.028), Keakuratan (0.030), Fleksibilitas (0.006) dan Ketepatan Waktu $(0,015)$ berpengaruh signifikan terhadap kepuasan konsumen pengguna sistem operasi andorid, dengan nilai koefisien positif sebesar 0.028, 0.030, 0.006 dan 0,015.

2. Berdasarkan hasil penelitian dengan mengguanakan regresi linear berganda menunjukan bahwa variabel Fitur berpengaruh signifikan terhadap kepuasan konsumen pengguna sistem operasi blackberry, dengan nilai koefisien positif sebesar 0,001 .

3. Berdasarkan hasil penelitian dengan mengguanakan regresi linear berganda menunjukan bahwa variabel Kemudahan penggunaan dan Dokumentasi, berpengaruh signifikan terhadap kepuasan konsumen pengguna sistem operasi IOS(Apple) dengan nilai koefisien positif sebesar 0,016 dan 0,020 .

4. Berdasarkan hasil penelitian dengan mengguanakan regresi linear berganda menunjukan bahwa variabel Fitur Ketepatan Waktu dan Dokumentasi, berpengaruh signifikan terhadap kepuasan konsumen pengguna sistem operasi Symbian (Nokia), dengan nilai koefisien positif sebesar 0,004, 0,015 dan 0,001 .

Berdasarkan hasil tersebut variabel Kemudahan penggunaan,, Keamanan, Produktivitas tidak signifikan dan berpengaruh negatif terhadap kepuasan konsumen.

Berdasarkan analisis kinerja SWOT yang telah dilakukan pada empat smatphone maka bisa disimpulkan perusahaan smartphone yang terbanyak pada kuadran I yaitu andorid, blackberry, iOS(Apple) dan Symbian(Nokia) dan IOS(Apple) pada kuadran II. Perusahaan dalam kuadran 1 menujukan usaha yang ideal yang terdapat pada sumbu $\mathrm{X}$ bernilai positif berati memiliki kekuatan (S) yang lebih besar daripada kelemahan (W). Sedangkan untuk sumbu Y bernilai positif dimana peluang (O) lebih kecil dibandingkan ancaman (T). Hal ini merupakan situasi yang sangat menguntungkan. perusahaan memiliki peluang dan kekuatan yang dapat dimanfaatkan untuk berkembang dan mengusai pangsa pasar smartphone di Indonesia yaitu dengan memanfaatkan seluruh kekuatan untuk merebut dan memanfaatkan peluang sebesar-besarnya. Strategi tersebut menggunakan kekuatan internal perusahaan untuk memanfaatkan peluang eksternal guna mengkonsentrasikan usaha.

Perusahaan pada kuadran 2 terletak pada sumbu X bernilai positif yaitu memiliki kekuatan (S) yang lebih besar daripada kelemahan (W). Pengalaman sebagai produsen perangkat keras dan perangkat lunak selama puluhan tahun serta dukungna developer yang handal menjadikan apple tetap mampu bersaing di pasar smartphone indonesia. Sedangkan untuk sumbu Y bernilai negatif yaitu memiliki peluang (O) lebih kecil daripada ancaman (W). Sehingga perlu dilakukan beberapa Diversifikasi Strategi untuk memperkecil faktor ancaman dan selalu menjaga Peluang bisnis. dengan melihat kondisi saat ini dan prediksi mendatang, masih cukup menguntungkan bagi apple untuk melebarkan usahanya. Diversifikasi Strategi merupakan kondisi dimana perusahaan mengalami ancaman namun masih memiliki kekuatan dari segi internal. strategis yang harus diterapkan adalah menggunakan kekuatan untuk memanfaatkan peluang jangka panjang. 


\section{DAFTAR PUSTAKA}

[1.] Kusuma, Yuliandi. 2011. Membedah Kehebatab Android. Grasindo. Jakarta Master.Com. 2012. All About Android. Kuncikom. Jakarta.

[2.] Rangkuti, Freddy. 1997. Analisis Swot Teknik Membedah Kasus Bisnis. Gramedia Pustaka Utama. Jakarta.

[3.] Setia Gunawan dan Bambang Dwi Atmiko. 2012. iPhone:From A to Z. Elex Media Komputindo. Jakarta.

[4.] Sugiyono. Prof.Dr. 2011. Metode Penelitian Kombinasi. Alfabeta. Bandung.

[5.] Sunyoto. Prof.J. M.A.,APU. 2006. Pengukuran Tingkat Kepuasan Pelanggan Untuk Menaikan Pangsa Pasar. Jakarta.

[6.] Sunyoto, Drs. Danang, SE., SH. MM. 2011. Analisis Regresi dan Uji Hipotesis. CAPS. Yogyakarta.

[7.] Tjiptono, Fandy.dkk. 2008. Pemasaran Strategik. Andi. Yogyakarta.

[8.] Priyanto, Dwi. 2012. Cara Kilat Belajar Analisis Data dengan SPSS 20. Andi. Yogyakarta.

[9.] Wahdi, Drs. Mohamad, MAB, 2011. Riset Pemasaran. CAPS. Yogyakarta.

[10.]Wijaya, Tony. 2011. Step by Step Cepat menguasai SPSS 19. Cahaya Atma. Yogyakarta. 